\title{
Narrativa testimonial y memoria pública en el contexto de la violencia política en Colombia
}

Testimonial narrative and public memory in the context of political violence in Colombia

\section{Martha CECiLia HeRrera}

Universidad Pedagógica Nacional · malaquita10@gmail.com

Docente investigadora de la Universidad Pedagógica Nacional. Magíster en Historia de la Universidad Nacional de Colombia (Colombia) y Doctora en Filosofía e Historia de la Educación de la Universidad Estadual de Campinas (Brasil). Fundadora del grupo de investigación Educación y Cultura Política.

\section{Carol Pertuz Bedoya}

Universidad Pedagógica Nacional · carolpertuz@hotmail.com Licenciada en Psicología y Pedagogía de la Universidad Pedagógica Nacional (Colombia). Tecnóloga en Sistematización de Datos de la Universidad Distrital Francisco José de Caldas. Miembro del grupo de investigación Educación y Cultura Política.

Resumen: Los sujetos afectados por el pasado reciente de la violencia política en Colombia han entrado en la agenda del Estado bajo la categoría del sujeto víctima desde la década del 2000 en el marco de nuevas disposiciones de las políticas públicas. El interés del presente artículo se centra en problematizar esta entrada desde los aportes de la narrativa testimonial para tensionar las diferentes expresiones que tienen lugar en la construcción de la memoria pública.

Palabras claves: Narrativa testimonial, Políticas de la memoria, Subjetividades, Colombia.
Resumen: The subjects affected by the recent past of political violence in Colombia have entered the agenda of the State under the category of 'victim' since the 2000 s under the new provisions of public policy. This article focuses this issue from the contributions of the testimonial narrative to between the different expressions that take place in the construction of public memory.

Palabras claves: Testimonial Narrative, Memory Policies, Subjectivities, Colombia. 
Marta C. Herrera y Carol Pertuz. Narrativa testimonial y memoria....

\section{Introducción: Cultura política y violencia en América Latina}

Los asuntos relacionados con la violencia política han ocupado un lugar destacado en el discurrir de la cultura política en América Latina, cuya dinámica -a partir de la instauración de los sistemas republicanos- ha estado pautada en buena medida por el uso de la fuerza y, en más de una ocasión, por las acciones armadas por parte de las distintas fuerzas sociales que se han disputado la representación política, las significaciones culturales y el acceso a los recursos estatales en los planos local, regional, y nacional. De este modo, la configuración de los estados nacionales y la construcción de comunidades nacionales imaginadas han debido sortear diversas tensiones en torno a los desajustes entre los lineamientos internacionales que han consagrado la normatividad que debe regir los modernos sistemas políticos en Occidente (así como la formación política del ciudadano que se considera inherente a ellos) y las prácticas políticas concretas desplegadas en distintas coyunturas históricas -las cuales han puesto en evidencia las propias temporalidades de los países latinoamericanos para insertarse en estas lógicas y, han develado, a su vez, las inconsistencias de las teorías que fundamentaron dichos lineamientos-. El análisis de la serie de problemáticas que de allí se desprenden, nos lleva a pensar que en los estudios sobre cultura política se debe considerar el componente violento y sus distintas modulaciones sociohistóricas, como inherente a las luchas en torno al poder político, con el fin de no limitarnos sólo a "añorar" su expulsión del campo político a partir de la sola invocación de su inadecuación o ilegitimidad para el accionar político, pues se dejaría de lado la complejidad que caracteriza la esfera política y las razones por las cuales la persistencia de la violencia se detecta aún en las sociedades modernas (Agamben, 1998; González, 2014).

De manera particular, la historia del siglo XX a partir de la segunda mitad, mostró un despliegue de violencia política agudo en el continente debido a las tensiones surgidas en torno a la configuración de los estados y los modelos de desarrollo introducidos las cuales dejaron al descubierto las expectativas de distintos sectores de la población por alcanzar niveles de vida satisfactorios y acceder a los derechos que pautaban los Estados de Bienestar. Algunas de estas expectativas dieron pie a la irrupción de demandas y protestas sociales que fueron canalizadas, en ocasiones, a través de gobiernos populistas, pero también por organizaciones de izquierda, varias de las cuales optaron por el camino de la lucha armada. Transcurridas las décadas de los 60 y los 70, las elites emprendieron medidas en torno al recorte de las reivindicaciones sociales y políticas logradas por los sectores populares y fuerzas de oposición, al tiempo que avanzaron en la puesta en marcha de modelos que ambientarían las condiciones de lo que se conocería como el neoliberalismo y su consecuente recorte del Estado de Bienestar, el cual encontró en Chile uno de los primeros laboratorios no sólo del continente sino del mundo entero (Moulian, 1991).

En el marco de este contexto y sus múltiples desdoblamientos en los diferentes países del continente, en Colombia se ha venido discutiendo en la agenda pública de las dos últimas décadas las 
posibilidades de poner fin al conflicto armado suscitado por la violencia política de los últimos cincuenta años, cuyas muertes han sido evaluadas por los estudios recientes en un total de 218.094 para el período 1958-2012 (Grupo de Memoria Histórica, 2013). Lo anterior, ha dado pie al surgimiento de múltiples narrativas que han tratado de explicar las causas de la violencia, los actores que la han vehiculizado y sus diversos intereses, así como las responsabilidades que ha tenido el Estado con relación a ella. En este entorno, a medida que las víctimas del conflicto cobran visibilidad los relatos testimoniales se han empezado a posicionar en la esfera pública confrontando las versiones oficiales sobre la violencia y disputando la memoria histórica en torno a los acontecimientos que la han pautado, al tiempo que han bosquejado algunas de las características de las subjetividades de quienes fueron afectados por dicha violencia (Dosse, 2009).

En el presente artículo, nos detendremos en varios de los trabajos de narrativa testimonial surgidos en el contexto colombiano. Si bien en ocasiones se nombrará un conjunto de obras por la pertinencia para nuestras argumentaciones, no pretendemos hacer un estado del arte sobre estas narrativas pues existen trabajos que se dedican a este propósito de manera amplia ${ }^{1}$; así, optamos por aludir a narrativas específicas que nos ayudan a elucidar las formas de configuración de las subjetividades y la presencia en ellas de múltiples figuras de sujeto que desbordan y problematizan la idea del sujeto víctima con la que la memoria oficial pretende condensar la experiencia vivida de quienes fueron afectados por la violencia política. El artículo plantea, en primer lugar, la visibilización del sujeto víctima en la agenda del Estado colombiano y las principales políticas públicas de memoria que han posibilitado su posicionamiento desde la década del 2000. En segundo lugar, se abordan varios relatos testimoniales sobre sujetos afectados por la violencia política para reivindicar su contribución a la construcción de memoria pública y a la pluralización de la figura del sujeto víctima. En tercer lugar, se llevan a cabo algunas reflexiones que ponen en tensión estas narrativas con la política pública de memoria para auscultar algunos de sus entrecruzamientos.

\section{El posicionamiento de las víctimas en la agenda del estado colombiano}

Las políticas de la memoria desplegadas en cada país obedecen tanto a lógicas particulares que atienden a los propios contextos internos y sus diversas coyunturas, como a su articulación con las políticas internacionales; mucho más en el contexto actual, de mayor intercambio e interdependencia a nivel global. Sobre este último aspecto, autores como Peris (2008), Vinyes (2009), y Richard (2010) han mostrado -apoyándose en Wieviorka (1998)- el predominio de un escenario internacional en el

1 Véase al respecto Vélez Rendón (2003); Franco, Nieto y Rincón (2010); Sánchez-Blake (2012); Verón (2011); Ortiz (1997) 
Marta C. Herrera y Carol Pertuz. Narrativa testimonialy memoria....

cual las políticas de la memoria privilegian los aspectos consensuales y dan a la figura de la víctima y a su testimonio un lugar que enfatiza en los aspectos atinentes al individuo, a sus sufrimientos físicos y psicológicos, desdibujando, así, los móviles históricos y las dimensiones políticas y sociales de la victimización. Como parte de esta tendencia estas políticas equiparan -en la mayoría de los casosvíctimas de distinta índole, vencedores y vencidos, con serias implicaciones para el esclarecimiento de las circunstancias históricas que propiciaron los hechos de violencia política, aspecto que pasa a un segundo plano y sustrae a la sociedad y a las nuevas generaciones la posibilidad de apropiarse del pasado y de leer en él sus repercusiones para el tiempo presente y el tiempo futuro.

Esta tendencia ha llevado a lo que Wieviorka denominó como la era del testigo, la cual puede rastrearse en las políticas de la memoria propuestas en varios países europeos, en Norteamérica y en América Latina, cuya génesis se sitúa en las tramitaciones que se hicieron sobre el pasado referido al Holocausto, la Shoa. Lo anterior, ha incidido en que varias de las narrativas testimoniales empiecen a ser moldeadas en esta dirección; así, en una primera fase, estas se situaron dentro del paradigma de la denuncia de los regímenes represivos y hacia la transmisión de una experiencia con énfasis en su carácter colectivo; en contraste, en la segunda fase, las memorias de las víctimas se destacan más desde su condición de individuos pertenecientes al género humano, con base en los lineamientos de los Derechos Humanos y el Derecho Internacional Humanitario, que han contribuido a posicionar una figura específica de sujeto en las sociedades contemporáneas y que, para el caso de los hechos aquí tratados, se cristalizó en la figura del sujeto-víctima. Este desplazamiento hacia lo consensual por parte de las políticas oficiales no dista de las modulaciones de sujeto pautadas desde las doctrinas neoliberales, cuyos primeros desarrollos se dan en las décadas de los 70 y 80 en América Latina; en estas, se privilegia la dimensión individual de las subjetividades, acorde con las condiciones del mercado y de las relaciones sociales de producción (Moulian, 1991; Peris, 2008).

Las iniciativas en torno a la memoria de las víctimas se han ido multiplicando en diversos escenarios sociales cobrando mayor relevancia desde la década del 2000 en el marco de las políticas estatales para lograr acuerdos con los grupos armados insurgentes y contrainsurgentes, incluidos los paramilitares y las organizaciones guerrilleras, FARC ${ }^{2}$ y el ELN³ . Así, durante el gobierno de Álvaro Uribe Vélez se expidió, en el 2005 la Ley de Justicia y Paz (Ley 975) y como parte de ella se creó la Comisión Nacional de Reparación y Reconciliación (CNRR) y el Grupo de Memoria Histórica encargado de investigar las causas, actores y repercusiones del conflicto armado reciente. Por su parte, en el 2011

\footnotetext{
2 Fuerzas Armadas Revolucionarias de Colombia.

${ }^{3}$ Ejército de Liberación Nacional.
} 
Marta C. Herrera y Carol Pertuz. Narrativa testimonial y memoria....

la Ley 1448 de víctimas y restitución de tierras dará un viraje a la política dando mayor posicionamiento a las víctimas y a su contribución a la memoria histórica.

Las diversas medidas que se pusieron en marcha para la implementación de la Ley de Justicia y Paz estuvieron pautadas por el énfasis en la desmovilización de los paramilitares, lo cual condujo a que sus testimonios se llevasen a los escenarios judiciales bajo un formato de versión libre. Así, las memorias de los miembros de estas organizaciones cobraron visibilidad en los medios de comunicación -interesados en que se les concediese el perdón legal y público-, en cuanto las víctimas quedaron en un segundo plano y, en más de una ocasión, fueron revictimizadas. Lo anterior, mereció el repudio de distintos sectores de la sociedad e influyó en la intensificación de iniciativas de memoria desde lugares ajenos al Estado, dentro de las cuales se cuenta el surgimiento del Movimiento Nacional de Víctimas de Crímenes de Estado (Movice), al cual se integraron cerca de 300 organizaciones de la sociedad civil, el cual situó como puntal estratégico la reivindicación de la memoria en la búsqueda de verdad, justicia y reparación, así como diversas propuestas en torno a las políticas de memoria pública (Movice, 2012).

La Ley de Justicia y Paz si bien consideró los intereses de los victimarios "sirvió como escenario, paradójicamente, para el posterior diseño institucional en materia de víctimas” (Sánchez, 2013: 64) y su emergencia en la esfera pública. En este contexto se expidió, en primer lugar, la Ley 1408 de 2010, "por la cual se rinde homenaje a las víctimas del delito de desaparición forzada y se dictan medidas para su localización e identificación" 4 y, finalmente, en segundo lugar, la Ley 1448 de víctimas y restitución de tierras, del 10 de junio de 2011, estableció nuevas reglas en torno a los procesos de justicia y reparación y colocó en primer lugar a las víctimas, en consonancia con la actual tendencia internacional y en contraste con la Ley de Justicia y Paz. Esta ley reconoce de manera explícita la existencia del conflicto armado en el país -situación desconocida por las dos administraciones anteriores de Álvaro Uribe Vélez (2002-2010) - al tiempo que sitúa un lugar para las víctimas: “El articulado allana el camino para el reconocimiento de las víctimas, sin importar quién fue su victimario, les reconoce derechos, otorga prioridades en el acceso a servicios del Estado y las convierte a ellas y sus familiares, en acreedores de una reparación integral” (Ley 1448, 2011). Aun así, esta ley sustrae la posibilidad de que se les otorgue el estatus de víctimas a los miembros de los grupos armados, por lo que se complejiza el reconocimiento de actos de violencia política estatal en contra de estos. Con esta ley se creó el Centro Nacional de Memoria Histórica al cual se adscribió el Grupo de Memoria Histórica, el cual publicó, en el 2013, el Informe ;Basta Ya! Colombia: Memorias de guerra y dignidad, producto de las investigaciones

\footnotetext{
${ }^{4}$ Congreso de la República de Colombia. Ley 1408 de 2010. Diario Oficial núm. 47.807 de agosto 20 de 2010.

5 Congreso de la República de Colombia. Ley 1448 de 2011. "Por la cual se dictan medidas de atención, asistencia y reparación integral a las víctimas del conflicto armado interno y se dictan otras disposiciones". s. d., 10 de junio de 2011.
} 
realizadas por un vasto equipo interdisciplinario que llevó a cabo un amplio estudio que incluyó a las víctimas y sus testimonios como parte vertebral de su trabajo ${ }^{6}$. Es a la luz de estas políticas que el tema de la memoria de las víctimas ha empezado a tener resonancia dentro de la agenda del Estado, al tiempo que la narrativa testimonial ha cobrado visibilidad aunque ya registraba desarrollos desde finales de los 80 en otros escenarios sociales.

En la actualidad el gobierno de Juan Manuel Santos se encuentra en procesos de diálogo con la guerrilla de las FARC y de manera más difusa con el ELN, el país entero está a la expectativa de que se logren acuerdos que permitan el cese del conflicto armado con estas organizaciones ${ }^{7}$. Empero, valga la pena aclarar, la consolidación de estas negociaciones no saldaría las diferentes aristas de la violencia política expresada en el país durante las últimas décadas, pues, sólo alude a la más aguda de ellas: la referente al conflicto armado -sin mencionar que dentro de ésta los crímenes de Estado no ocupan un lugar relevante-. Al respecto, se torna pertinente recordar la delimitación que hace la Comisión Colombiana de Juristas según la cual, la violencia política en el país implicaría "hechos que configuran agresiones contra la vida, la integridad y la libertad personal producidos por abuso de autoridad de agentes del Estado, los originados en motivaciones políticas, o los causados por el conflicto armado interno" (2004: 17).

De este modo, el posicionamiento de las víctimas en la agenda del Estado y en la memoria oficial solo tiene como antecedentes, en el caso colombiano, las dos primeras décadas del siglo XXI, lo cual implica, por un lado, un logro sin precedentes que ha permitido la validación nacional e internacional del carácter político del conflicto colombiano y con ello la posibilidad de que los sujetos afectados por la violencia accedan a los recursos del Estado para obtener medidas de verdad, justicia, reparación y garantías de no repetición, con base en su reconocimiento como sujetos de derecho; y, por otro lado, la presencia de una memoria oficial que desdibuja algunas de las aristas que permiten pensar estos sujetos más allá del referente de la victimización al instituirlos desde el paradigma del sujeto-víctima. Lo anterior, señala la importancia de visibilizar otras prácticas y otros referentes que alimentan el campo de la memoria pública y controvierten la perspectiva individualizante de este paradigma y la homogenización de las víctimas. En este sentido es pertinente referenciar la narrativa testimonial como uno de los ámbitos en los que se alude a los sujetos afectados por la violencia y a partir del cual es posible indagar respecto a su mayor o menor presencia en el escenario público.

\footnotetext{
${ }^{6}$ Ver: http://www.centrodememoriahistorica.gov.co/

${ }^{7}$ En el caso de las negociaciones con las FARC las dos partes anunciaron el 23 de septiembre de 2015 la factibilidad de firmar un acuerdo definitivo que lleve a la dejación de las armas de esta organización y su reinserción a la vida civil en marzo de 2016. Uno de los aspectos que más ha complejizado las negociaciones se refiere a las víctimas.
} 
Marta C. Herrera y Carol Pertuz. Narrativa testimonialy memoria....

\section{El sujeto víctima y su posicionamiento en las narrativas testimoniales}

Las narrativas testimoniales que integraron nuestro corpus documental arrojan algunas luces respecto de las modalidades de constitución de las subjetividades de sus autores o protagonistas y de los escenarios en los cuales se configuraron y modularon sus contextos de enunciación. A través de ellas sus autores interpelan en torno a ciertos imaginarios y representaciones que pautan las formas de comprensión sobre el conflicto, el orden social y las subjetividades -no solo de quienes escriben, sino también de quienes son sus receptores-. En esta medida, dichas narrativas inciden en la formación de los sujetos, hallándose inscritas, es claro, en un marco mucho más complejo en el que distintas fuerzas y actores disputan las significaciones en torno al ser o el deber ser de la sociedad y los grupos e individuos que la integran. En este sentido, entendemos que "la narrativa no es el lugar de irrupción de la subjetividad, de la experiencia de sí, sino la modalidad discursiva que establece tanto la posición del sujeto que habla (el narrador) como las reglas de su propia inserción en el interior de una trama" (Larrosa, 1995: 310). Por ello, al considerarse la constitución narrativa de la experiencia de sí, situada histórica y culturalmente, es posible leer, a través de ésta, los signos de una época así como las condiciones de posibilidad que han pautado dicha experiencia.

La invisibilidad que han tenido los sujetos signados de manera directa por la violencia en el contexto del conflicto político colombiano, así como las diversas categorías que los nombran, es atribuida por distintos analistas a la permanencia del conflicto armado y a la complicidad de sectores de la sociedad y del Estado, hecho que ha dificultado la instauración de contextos de enunciación en los cuales los sujetos puedan desplegar sus narrativas y posicionarse en relación con los acontecimientos en los que se vieron implicados, al tiempo que viabilizar agenciamientos de distinto orden en torno a ellos. Según Verón (2011), la palabra víctima adquiere posicionamiento en el escenario público a partir de la década del 80 debido, en parte, a la circulación de relatos testimoniales en los que se alude al sujeto que ha sido víctima de hechos relacionados bien sea con el desplazamiento, con la militancia política o con situaciones de secuestro. No obstante, como ya se mencionó, en la política pública su visibilización se empieza a dar desde la década del 2000.

Quienes fueron objeto de la violencia política estatal tuvieron que enfrentarse a la mirada de los agentes de dicha violencia sobre ellos: los calificaron como ajenos al cuerpo social, como enemigos de la sociedad. Tuvieron que lidiar con las interpelaciones que estas miradas hacían frente a los proyectos y a las organizaciones políticas (algunas armadas) que les habían estructurado como sujetos. De esta manera, frente a las subjetividades que habían sido moduladas a la luz de un contexto histórico que promovió la utopía de un cambio social de carácter revolucionario en las décadas del 60 y el 70 del siglo 
pasado, y que propició el surgimiento de organizaciones políticas de diversos tipos, así como el auge de movimientos sociales que contestaban al orden social capitalista, los sujetos debieron enfrentar la violencia estatal que arremetió contra los imaginarios que sustentaban este tipo de idearios y quebrantó las organizaciones, diezmando sus filas a través de la represión y la descalificación de su representación política en el marco del orden burgués. De allí, emergieron imágenes que aluden a sujetos fragmentados: al desaparecido cuya presencia es la huella de lo ausente, al encapuchado que no puede verse a sí mismo en su totalidad y tampoco puede ver a los otros, a la ubicuidad del nombre, al héroe, al mártir, al traidor, al quebrado, al renegado, al subversivo, al militante, al guerrero y al inocente, a trazos borrosos en los que se mezcla la figura de la víctima y el victimario de manera amenazante, entre otras. Así mismo, los desdoblamientos de la violencia dados en los años 90 y 2000 complejizaron el contexto y los actores (auge del paramilitarismo y presencia del narcotráfico) y dejaron emerger a través de las masacres, el desplazamiento y la desaparición forzada una amplia gama de sujetos que desbordan la idea del sujeto militante y llevan a hablar, de manera polémica, de guerra contra la sociedad (Pecaut, 2001).

\subsection{Narrativas testimoniales de militantes}

Un vistazo a la producción testimonial permite ver despliegues narrativos relacionados con relatos de militantes provenientes de organizaciones políticas que después de actuar como grupos guerrilleros se reinsertaron a la vida civil a comienzos de los 90 , en donde sus vivencias tienen como desdoblamiento su participación en la vida política nacional, como es el caso de integrantes del M-19 o de la Corriente de Renovación Socialista, con una variedad de elecciones existenciales y de nuevas militancias políticas. También están los relatos de quienes pertenecieron a la Unión Patriótica en los que se narran las prácticas de aniquilación sobre esta organización ${ }^{8}$. Otras son las narrativas de miembros de organizaciones que aún continúan en la clandestinidad y enfrentan al Estado en su calidad de grupos guerrilleros, como es el caso de las FARC y el ELN. De acuerdo con estas distintas vivencias, los matices en la configuración de subjetividades políticas se amplían tanto en lo referente a las perspectivas desde las cuales los sujetos abordan los recuerdos sobre el pasado y su posicionamiento sobre el presente, como en lo referente a los horizontes de futuro; así pertenezcan a un mismo contexto histórico y a la misma coyuntura política, existen marcas diferenciadas en lo que respecta a la dinámica de las organizaciones en las cuales se militaba y a su transcurrir en el espacio público, así como en las maneras de verse a sí mismos. Adicionalmente, habría que precisar que en más de un caso hay sujetos que han

\footnotetext{
${ }^{8}$ si bien, varios de sus miembros participan en la actualidad en la esfera política desde otras afiliaciones o pugnan por el reposicionamiento de la Unión Patriótica.
} 
Marta C. Herrera y Carol Pertuz. Narrativa testimonial y memoria....

militado en más de una de estas organizaciones e incluso en las filas del paramilitarismo; algo explicable, en parte, por la larga duración del conflicto.

Desde esta perspectiva, varios relatos testimoniales muestran un panorama de los diversos sujetos involucrados en el conflicto, algunos de ellos elaborados por lo que Verón denomina como el escritortestigo que sirve de mediador a quienes vivenciaron de manera directa acontecimientos relacionados con el conflicto armado y la violencia política. En esta dirección se encuentra el libro de la periodista Patricia Lara Las mujeres de la guerra (2000), en el cual se presentan los testimonios de diez mujeres que han tenido diferentes experiencias y en cuya selección se ve la intención de desplegar un abanico amplio de personas, sujetos y actores, marcados por la violencia. Dentro de las mujeres que narran sus vivencias, se cuentan una ex militante del ELN y el M-19, una comandante de las FARC, así como una dirigente de las autodefensas (paramilitares) que había sido simpatizante del ELN.

Dora Margarita, una de las mujeres que aparece en la obra de Lara, es personaje construido ficcionalmente con la fusión de los testimonios de dos mujeres, y que da cuenta del paso de este personaje por dos organizaciones, el ELN y el M-19. En uno de los pasajes Dora Margarita se refiere a la presencia permanente de la muerte y a la dificultad de su tramitación subjetiva marcada por el peso de la vida clandestina que implica la militancia en organizaciones guerrilleras:

Lo más duro de la guerra es la muerte, la pérdida de los compañeros son dolores que se van acumulando. Uno no es consciente de ello mientras está en la lucha. Pero cuando para, lo devora a uno el dolor de cada muerto, de todos los muertos. Y lo que más lacera es que en la vida clandestina hay que ocultar los dolores, porque son producidos por muertos estigmatizados. Y ese ocultamiento hace que las heridas nunca sanen. Entonces los dolores quedan, se eternizan (Dora Margarita, exguerrillera del ELN y el M-19 en Lara, 2000: 70).

Existen algunos relatos sobre el M-19 referidos a trayectorias de militantes de esta organización, dentro de los cuales se destacan trabajos autobiográficos como el de María Eugenia Vázquez Escrito para no morir (2000) y el de Vera Grabe, Razones de vida (2000). También, Siembra vientos y recogerás tempestades: La historia del M-19, sus protagonistas y sus destinos de Patricia Lara (1982); y, Mi guerra es la paz, de Juan Carlos Iragorri sobre Antonio Navarro Wolff, (2004, reeditado 2009). Por su parte Andrés Peralta Gómez, desmovilizado del M-19, ha publicado varios libros en torno a narrativas de reinsertados: ¿Valió la Pena? Testimonios de excombatientes en la vida civil (2004), elaborado en conjunto con Otty Patiño; La guerra para qué (2008); y, La Vida no da Tregua (2011). Estos trabajos han sido mediados por iniciativas de ONG y/o organismos estatales que han convocado a personas que militaron en organizaciones armadas y que en la actualidad se encuentran reinsertados a la vida civil para que a través de talleres de escritura conversen, compartan sus experiencias y escriban en torno a ellas. En el libro ¿Valió la Pena? Peralta y Patiño editan y publican testimonios de ex combatientes del M-19, 
EPL ${ }^{9}$ y FARC, bajo el auspicio del Observatorio para la Paz creado en 1996 por Vera Grabe. En la introducción Peralta y Patiño, a su vez dos ex militantes del M-19, enuncian el propósito de su trabajo editorial de la siguiente manera:

Si estos testimonios sirven para demostrar, una vez más, que la paz -aún la incierta paz que surge de una solución negociada- es más digna y más humana que la más justa de las guerras, habremos logrado nuestro cometido. También si al final de la lectura hombres y mujeres que vivieron y leyeron estas historias pueden, con la sonrisa plena, reconocer que el dilema no era vencer o morir, que nuestra obligación en Colombia era y sigue siendo vencer a la muerte (13).

En uno de los testimonios, el de Mauro, podemos encontrar la presencia de la muerte como un detonante en las experiencias de los sujetos, como marca que incide en sus juicios y actuaciones, en su devenir como militantes:

En 1987 abandoné la militancia en el M-19 después de la muerte de Jorge Carvajalino o "Nelson"... Al otro día, leí en la prensa que él y su hermano "Ariel" habían sido muertos por la Policía [...] Las ganas de seguir en los azares de la vida clandestina ya se me habían enfriado desde el holocausto del Palacio de Justicia, donde las razones políticas se impusieron sobre la razones de vida y las carcajadas de la muerte resonaron macabras en el corazón de Bogotá, en la Plaza de Bolívar (53).

La figura del subversivo emerge en las narrativas llena de ambigüedades y de zonas oscuras al ser desplegada por los aparatos represivos para imponer el disciplinamiento en torno a lo que el orden social establecido consideraba el sujeto permitido, legitimado. Vera Grabe (2000) dirigente del M-19, alude a los desbordamientos de esta figura al conjunto de la sociedad y las tecnologías represivas puestas en marcha, en especial, durante la presidencia de Turbay Ayala (1978-1982) para conjurar su presencia en el espacio social:

El ejército detenía no sólo a reales o supuestos miembros del M-19, sino a todo el mundo. En una cacería de brujas sin precedentes fueron a parar a la Escuela de Caballería de Usaquén poetas, periodistas, sindicalistas, activistas, sociólogos, demócratas, estudiantes, dirigentes campesinos, y un montón de gente que nada tenía que ver con la insurgencia. Todo lo que oliera a izquierda, a derechos humanos, a inconformismo o crítica, era tachado de subversivo [...] Los abusos, retenciones irregulares, interrogatorios, amenazas, eran contundentes [...] Por primera vez se hablaba con fuerza de la existencia de presos políticos (Grabe, 2000: 95).

En este relato podemos ver desplegarse además de la figura del sujeto/subversivo impuesta desde la represión, la figura del sujeto/preso político puesta en circulación por las organizaciones políticas y por los organismos de derechos humanos. Esta figura del sujeto/preso político arroja luces sobre el perfil del militante ya no visto como subversivo sino como un individuo con un ideario político en franca

\footnotetext{
${ }^{9}$ Ejército Popular de Liberación.
} 
oposición al orden social establecido y objeto de persecución por parte del Estado debido a sus actuaciones políticas. En el libro de Grabe hay un pasaje en el que se despliegan imágenes de cómo se ve a sí misma como sujeto militante que encarna un ideal colectivo en donde surge también la figura del guerrero y la legitimidad moral que da a sus actuaciones:

Se me viene inmediatamente la imagen nuestra, como guerreros limpios, de honor en aquella época. [...] me asaltan de inmediato la mujer y la comandante fusionadas para subsistir en la guerrera, aquella cuyos códigos particulares hacían que considerara la guerra como el escenario moral en donde se manifiestan las grandes virtudes -diría Ignatieff-, donde los combatientes distinguían los objetivos legítimos de los no legítimos, las armas morales de las no morales (Grabe, 2000: 317).

La figura del desaparecido recorre también la escena política colombiana por lo general de la mano de relatos de madres, esposas, amantes e hijos/as de quienes fueron alcanzados por la violencia estatal y paraestatal, pero también contrainsurgente. En Mujeres de Fuego, de Alonso Salazar (1993), uno de los relatos pertenece a la madre de un joven militante de las juventudes comunistas que desapareció en el año 1984, después de haber sido detenido por el ejército. En él se recrea la búsqueda de su hijo y las innumerables diligencias hechas por ella ante autoridades nacionales, así como sus denuncias ante la Comisión Interamericana de Derechos Humanos, constituyéndose en una de las primeras víctimas de desaparición forzada reconocidas en Colombia ${ }^{10}$. Frente a la figura de su hijo como desaparecido Fabiola dice:

Es un drama desgarrador: ¿Qué sentido tiene seguir esperando indefinidamente un reencuentro? Mantener vivo el recuerdo es echarle sal a la herida. Pero, si está en algún lugar y lo dejo de buscar ¿qué? Me piden resignación, pero para resignarme necesito la evidencia: Este es Luis Fernando, ya sé que está muerto, le voy a dar cristiana sepultura. No lo puedo enterrar sin encontrarlo, ni siquiera en los sueños lo hemos visto muerto (193).

Las Horas Secretas de Ana María Jaramillo (1990), una narrativa que gira en torno a la Toma del Palacio de Justicia, tiene como protagonista a la amante de Alfonso Jacquin, un dirigente del M-19 que participó en la Toma y cuyo cuerpo nunca pudo ser encontrado. Esta novela testimonial se acerca a los hechos desde otro lugar para posicionar, por un lado, el tema de los desaparecidos del Palacio -no solo los trabajadores de la cafetería y visitantes ocasionales- y, por el otro, recrear la vida cotidiana -a través de un relato que deja al descubierto la pasión y el erotismo como dimensión de las subjetividades- y el

\footnotetext{
${ }^{10}$ En 1992 un juez penal militar ordenó la exhumación de los restos de un cuerpo que permitieron identificar al hijo de Fabiola, quien a lo largo de su búsqueda y de la lucha porque se hiciese justicia sobre los responsables fue acopiando pruebas documentales que, en más de una ocasión, corrieron peligro de desaparición. Fabiola llamó a su búsqueda operación Sirirí en alusión a un pájaro que defiende con firmeza sus crías de los depredadores. Finalmente, los archivos acopiados por Fabiola a lo largo de treinta años fueron donados al Centro de Memoria Histórica y acaban de ser declarados por la UNESCO patrimonio de la humanidad (Serralde, 2015, 29 de octubre).
} 
accionar político de esta organización. Mery Cruz (2005), se refiere a este texto como una escritura femenina que propone nuevos lenguajes para nombrar desde otro lugar acontecimientos políticos que sacudieron al país y entrever la figura del sujeto militante. En sus palabras:

La narradora nos da testimonio de un soñador, en una época donde todavía se creía en las utopías, en la lucha armada y política como vía para la construcción de sociedades más justas e igualitarias. La obra nos presenta un sueño colectivo, a través de un discurso plagado de consignas que nos hacen devolver a la efervescencia, que todavía, en los años ochenta tenía eco en el mundo, pero que muy pronto se precipitaría en el olvido, y que sonaría obsoleta (56).

La tortura cuyo referente inmediato es el dolor físico y la amenaza de muerte su consecuencia límite, interviene en la configuración de las subjetividades y representa el mayor de los desafíos que debieron enfrentar los sujetos militantes. No en vano la autobiografía de María Eugenia Vásquez, miembro del M-19, lleva por título Escrito para no morir como una expresión de que su reconfiguración subjetiva tuvo que atravesar múltiples elaboraciones en relación con la muerte. Cuando Vásquez (2000) reflexiona en torno a su proceso de reinserción a la vida civil, menciona la idea de un tipo de subjetividad que anuda al sujeto guerrillero, en donde son constantes los referentes a la muerte, no sólo por sus propias vivencias sino también por la forma como la miran personas cercanas a ella:

Un miedo colectivo hacía difícil mi relación con la gente (...). Casi todos los conocidos me percibían como posibilidad de muerte, portadora de peligro en mi carácter de perseguida. Entendía su miedo pero me dolía el rechazo; nadie parecía percatarse de mi fragilidad interior, al fin y al cabo proyectaba un estereotipo de fortaleza. En esos momentos, quise ensayar otras opciones de vida, pero estaba etiquetada como guerrillera, con la marca de la muerte sobre la frente (483).

El sometimiento a la tortura pone a prueba a los sujetos y, en ocasiones, puede ser procesada como una vivencia de la cual reemerge el sujeto, bien sea quebrado o no, pero en cualquiera de los casos, como un sujeto diferente, como un sujeto marcado: "Si descendía a los infiernos y no me quebraba, si salía libre y fortalecida, renacería limpia, generosa, renovada. Si me quebraba -que es peor que morir-, tardaría en poder volver a mirarme al espejo. Pero en todo caso nada iba a ser como antes" (Grabe: 98-99). Pero no todos los relatos podían narrar el no haber cantado, no haberse quebrado en las sesiones de tortura, las sombras sobre lo que pasaba en aquellos parajes y lo que habrían podido decir o hacer los sujetos en estas condiciones límites en la búsqueda de la sobrevivencia, permanecían como una incógnita. En el texto Operación Ballena Azul. Las armas del Cantón Norte, Hollman Morris (2011) alude al sometimiento a la tortura del que fue víctima un militante, dirigente, del M-19, en las caballerizas del ejército:

Isidro: -Llegamos a algo frío y húmedo con una resonancia especial que parecía una caverna. Allí me desnudaron, me vendaron los ojos, me subieron encima de una mesa, me ataron las 
Marta C. Herrera y Carol Pertuz. Narrativa testimonial y memoria....

manos atrás y luego quitaron la mesa y quedé suspendido en el aire y ahí empezó la paliza [...] El comandante Isidro no aguantó la tortura, psicológicamente nadie lo preparó para ello, el movimiento guerrillero M-19 estaba dispuesto para los golpes más audaces, sus hombres estaban dispuestos a dar la vida, pero hasta ese momento, enero de 1979, nunca estuvieron preparados para la tortura (5-6).

León Valencia fue un líder del grupo guerrillero ELN durante los años 80 y propició en los 90 una disidencia llamada Corriente de Renovación Socialista, la cual dirigió hasta la firma de un acuerdo de paz en 1994. En la actualidad es experto en Derechos Humanos y en estudios sobre el conflicto armado colombiano. Valencia publicó, en 2008, el libro Mis años de Guerra, mientras se encontraba en el exilio; en el prólogo del texto menciona el propósito de controvertir, a través de sus memorias, a quienes le acusan de no tener autoridad moral para hablar de estos temas en el escenario público por sus actuaciones anteriores como guerrillero y señala la estela de muertes que ha cobrado el conflicto e indica su decisión de abandonar el camino de las armas por las experiencias dolorosas vividas bajo la acechanza permanente de la muerte, así como el cambio que hizo en su escala de valores para distanciarse de esta opción:

Había dejado las filas guerrilleras porque había comprendido, mediante el dolor de saber a mis amigos muertos, mediante la angustia que trae la pérdida de seres entrañables, que la vida, la que nos ha tocado trasegar o presenciar, está por encima de todos los demás valores. Fue un cambio en la escala de valores lo que me llevó a la paz (19-20).

León Valencia se refiere también a la figura de la traición como una impronta que marca a quienes como él se reinsertaron a la vida civil. Al abandonar el camino de las armas, los reinsertados suscitan la suspicacia en antiguos compañeros de militancia. Al mismo tiempo, se interroga por cómo evaluar sus acciones pasadas como sujeto: "Este libro atiende al eco que aún deja en mi interior la palabra traidor, pero sobre todo está dedicado a la palabra vergüenza. ¿Debo avergonzarme de mi pasado? ¿De qué parte de él debo hacerlo y de qué parte no?” (18-21).

Otra veta de la narrativa testimonial se ha referido a la violencia estatal y paraestatal llevada a cabo en contra de La Unión Patriótica, un partido político constituido en 1985 como parte de los procesos de negociación con las FARC para su inclusión en la vida civil, la dejación de las armas y la participación política. Este partido fue conformado por diversas fuerzas de oposición provenientes de la izquierda y de otros sectores democráticos que le apostaron a acuerdos civilistas y a la participación política por la vía legal. La UP ganó fuerza en diversas partes del país, en especial en las regiones rurales, alcanzando escaños en alcaldías, gobernaciones y otros cargos públicos. No obstante, se inició un proceso de exterminio que llevó, a través de muertes selectivas y numerosas masacres y desplazamientos, a la liquidación, según algunas de las fuentes, de más de 4.000 militantes y el asesinato de dos candidatos presidenciales, así como al exilio de muchos de los sobrevivientes de esta organización. La memoria de la 
UP y de los sujetos que fueron signados por dicha opción política está marcada por las pérdidas, por las ausencias y por la lucha continua por su visibilización a nivel histórico.

En el documental Esperanza es lo que hay por ahí se encuentran distintas referencias al impacto que causó la experiencia de la UP sobre la memoria colectiva. Cuando se hace mención a la creación en el año 2000 del Movimiento Bolivariano, por iniciativa de las FARC, con el propósito de unificar las fuerzas de oposición, se alude a que deberá tener un carácter clandestino para evitar el exterminio de sus integrantes. En este sentido la voz en off señala: "La sangrienta lección de la UP no solo dificulta una salida política para la insurgencia sino que es también un lastre para los grupos políticos que pretendan promover los cambios que la sociedad colombiana necesita”. Por su parte, en el documental Mujeres de la Unión Patriótica (Morris, 2012) se incluyen los testimonios de cuatro mujeres que fueron militantes de la UP: Patricia Ariza, Odilia León, Adela Solano, Gloria Inés Ramírez, en los cuales puede verse el impacto que el terrorismo de estado ha dejado sobre sus subjetividades. En estos testimonios se alude a configuraciones subjetivas en las que, en una primera fase, se presenta una especie de parálisis en la vida cotidiana y en las expectativas de acción política, pero en un segundo momento, pasados los años y procesadas las experiencias, se alude a la reconfiguración del sujeto mediada por los compromisos adquiridos con procesos de acción social, artística, sindical y política, así como de la reivindicación de la UP como una opción política cuya memoria están dispuestas a rescatar.

En la producción narrativa colombiana, en su multiplicidad de formatos, ha empezado también a perfilarse la presencia de los/las hijos/hijas ${ }^{11}$ que desde su propio presente han tratado de explicarse los acontecimientos políticos de las décadas anteriores y en los que sus padres fueron protagonistas, con el propósito de llenar las ausencias que dejaron en sus vidas y conjurar el olvido político que predomina en la esfera pública en torno a ellos. Dentro de esta producción se encuentran los documentales Carlos Pizarro: un guerrero de paz (2010) y Pizarro: la película (2015) hechos por María José, hija de Carlos Pizarro León Gómez, comandante del M-19 asesinado en plena campaña presidencial, después de la reinserción del movimiento a la vida política, cuando ella tenía 12 años. María José dice que sus trabajos constituyen una apuesta por reconstruir la memoria de su padre y los ideales que se afincaron en la generación de la que él fue parte. Asimismo, la autora precisa algunos de los interlocutores a quienes pretende llegar a través del libro De su puño y letra (2015) en el que compila cartas escritas por su padre:

Está dedicado especialmente a los hijos e hijas de la insurgencia armada porque de nosotros poco o nada se conoce, de cómo hemos podido asimilar experiencias como la clandestinidad, la persecución, el desarraigo de la separación, la orfandad, las vivencias de una vida simulada, oculta, de la que pocos hemos podido hablar y en estas cartas se encuentran razones y respuestas que hemos estado buscando y solo nuestros padres podían dar. Para los victimarios también ha

\footnotetext{
${ }^{11}$ No sólo hijos/hijas. Esta es una manera de aludir a los nexos generacionales.
} 
Marta C. Herrera y Carol Pertuz. Narrativa testimonial y memoria....

sido trascrito este libro, porque terca y ciegamente no se puede insistir en que la solución de un conflicto es borrar las ideas con pólvora y que las raíces de estas guerras que tanto tiempo han permanecido, son la obstinación necia de no admitir cambios. En ellas, la otra orilla habla y revela la cara humana de ese enemigo que se ha eliminado sistemáticamente (Pizarro, en Semana 21 de Abril, 2015).

\subsection{Narrativas testimoniales en torno al desplazamiento, las masacres y la desaparición forzada}

La larga duración del conflicto ha complejizado de manera singular la dinámica, los actores y los intereses de la violencia política, al tiempo que ha expandido sus márgenes de influencia a todo el territorio nacional, afectando a una significativa parte de la población a través del desplazamiento y de las masacres -en especial en las áreas rurales o en zonas urbanas marginadas-. Este fenómeno ha encontrado tratamiento en la narrativa testimonial reciente con marcada relevancia, arrojando luces sobre imágenes de sujeto que aluden al desplazado y al desaparecido. Una mirada hacia las narrativas testimoniales que giran en torno a estos fenómenos permite vislumbrar la presencia de matrices discursivas provenientes de distintas iniciativas. Encontramos, por ejemplo, relatos novelados en donde sus autores hacen uso del artificio literario para crear personajes y tejer tramas ficcionales a partir de acontecimientos registrados en la historia del país; tales relatos si bien se construyen a partir de las vivencias de los personajes, se valen de elementos de veridicción (Ochando, 1998) desde los cuales establecen lazos con los hechos reales; es el caso de obras como En el brazo del río de Marbel Sandoval (2006); Los muertos no se cuentan así de Mary Daza (1991); Las horas secretas de Ana María Jaramillo (1990); Vivir sin los otros, Los desaparecidos del Palacio de Justicia de Fernando González (2010); Noches de humo de Olga Behar (1988), entre otras.

También se encuentran narrativas derivadas de procesos de reparación y de formación como los llevados a cabo en el marco del proyecto "Víctimas del conflicto armado" del programa Paz y Reconciliación, a través del cual la Secretaría de Gobierno de la Alcaldía de Medellín pretendió “contribuir a la dignificación y rehabilitación de las personas que han padecido la guerra en la ciudad [...] mediante el arrebato al olvido de sus historias" (Villegas en Nieto, 2006: 8). Algunas de estas iniciativas, como es el caso de Jamás olvidaré tu nombre (Nieto, 2006), fueron el resultado de una serie de búsquedas propiciadas por un equipo de periodistas con diversas personas desplazadas de sus tierras y que llegaron a vivir a los barrios marginales de Medellín. En los relatos que construyen las personas vinculadas al proyecto, la compiladora Patricia Nieto reconoce una "conciencia de la existencia" como condición de posibilidad de la escritura. Asimismo, en el proyecto subsiguiente, El cielo no me abandona (Nieto, 2007), el cual se consolidó a partir del taller de escritura denominado "De su puño y letra. Polifonía para la memoria. Las voces de las víctimas del conflicto armado en Medellín”, planteó las 
Marta C. Herrera y Carol Pertuz. Narrativa testimonialy memoria....

posibilidades de las memorias personales de un pasado doloroso en la consolidación de memorias ejemplarizantes y en la contribución a la no repetición de hechos victimizantes (Fajardo en Nieto, 2007: $7)$.

Por otro lado se encuentran los documentales e informes producidos por el Grupo de Memoria Histórica y el Centro Nacional de Memoria Histórica, los cuales, por la naturaleza de la entidad, empiezan a formar parte de la memoria oficial. Estas narrativas aluden a temáticas como justicia y paz, género, casos emblemáticos y, despojo, desplazamiento y resistencia. Algunos de estos informes han recogido diversas iniciativas de memoria provenientes de organizaciones sociales (GMH, 2009).

Otras narrativas provienen de la crónica y la investigación periodística así como proyectos fotográficos y documentales, en estas lógicas se cuentan los trabajos de Patricia Nieto con Los Escogidos (2012); Germán Castro Caycedo con El Palacio sin máscara (2008); Ramón Jimeno con Noche de Lobos (1986); Juan Manuel Echavarría con Réquiem NN; Jesús Abad Colorado con Mirar la vida profunda (2015); Gabriel Posada y Yorlady Ruíz con Magdalenas por el Cauca (2008); y, Hollman Morris y Juan José Lozano con Impunity (2010), entre otros.

Con la novela En el brazo de río, Marbel Sandoval construye una narrativa ficcional en la cual, a partir de la alternancia de las voces de Sierva María y de Paulina, dos adolescentes, relata varias aristas del conflicto colombiano: el drama del desplazamiento, la sucesión de masacres y el duelo irrealizable que supone la desaparición. La narrativa remite a la masacre ocurrida en 1984 en la vereda Vuelta Acuña del Municipio de Cimitarra. Además de la ilación de las voces de Paulina y Sierva María, Sandoval trae los textos de algunas noticias publicadas en el periódico Vanguardia Liberal que entran en el relato como parte de un cuaderno de recortes que Sierva María empieza a construir a partir de la desaparición de Paulina de quien, se presume, cayó víctima de la masacre. Sierva María intenta reconstruir hechos que la conduzcan a saber qué pasó con su compañera. A lo largo de todo el relato ronda la referencia a la necesidad de ver, escuchar y leer para "formarse su propia opinión”, y es eso justamente lo que Sierva María intenta, viendo las hordas de campesinos que llegan a Barrancabermeja y buscan refugio en los patios de las escuelas y en los parques, o escuchando las versiones de las vecinas que mandan a confeccionar vestidos a su mamá o buscando en la prensa noticias que den cuenta de la masacre en la que desapareció Paulina. Son múltiples los interrogantes, imposibles las preguntas y difíciles las respuestas que implican el "formarse la propia opinión” tratando de comprender la masacre, el desplazamiento y la desaparición como partes de un todo, en un contexto en el cual los perpetradores no reivindican la autoría de las masacres:

De manera que no solo los mataban sino que también les quitaban el derecho a que sus familias continuaran en su tierra. ¿O sería que toda esa sangre derramada no era sino para apoderarse de 
Marta C. Herrera y Carol Pertuz. Narrativa testimonial y memoria....

la tierra?, me pregunté y me di cuenta de que cuando el padre Eduardo me invitó a que me formara mis propios conceptos me puso en situaciones difíciles. Detrás de cada hecho tuve que aprender a preguntarme cuál era su motivo y a no conformarme con las primeras respuestas que me llegaban. Era como descorrer velos y velos para llegar al último. Igual me había pasado con las noticias. Ahora las leía con desconfianza y con cuidado. Para eso tenía mi cuaderno de recortes. Es posible que llegara a coleccionar todo lo que decían de un mismo hecho, pero ¿cuál sería la verdad? (Relato de Sierva María en Sandoval, 2006: 123).

Por su parte, Patricia Nieto escribe en Los Escogidos una crónica de viaje a Puerto Berrío. Desde allí, con las voces de los vivos, sus rituales y sus prácticas reconstruye las trayectorias de muerte de los desaparecidos en el río Magdalena. Allí estará también su experiencia de paso por el Pabellón de los Olvidados, el lugar del cementerio de Puerto Berrío donde se encuentran los muertos sin nombre rescatados del río por los habitantes:

¿Quién yace en la primera bóveda de este albergue de los olvidados. De cuál linaje se desgranó sin dejar huella. Cómo se llama el que aquí se deshace mientras pasa el tiempo. Cuáles palabras susurró o -quizá- gritó mientras le quitaban la vida. Quién lo busca. Por dónde vagan los que lo lloran. Cómo llegó a este puerto de cuerpos sin nombre? 'Es un muerto del agua', dice alguien al pasar (Nieto, 2012: 17).

Nieto cuenta, además, la práctica de adopción de ene enes a través de la cual hombres y mujeres reconfortan "sus vidas sitiadas por la pobreza y por la violencia” (Alarcón en Nieto: 13). En Los escogidos el ritual -aún el del científico- y la mística -de los creyentes que se convierten en dolientes y en beneficiarios de las ánimas-, se resisten al robo de la identidad a través de intentos por reconstruir las pistas de las últimas horas y de prácticas como asignar nombres y dotar de vida la entidad del muerto para volverlo parte de la cotidianidad. Patricia Nieto refiere en varias oportunidades los procedimientos llevados a cabo por los forenses de Medicina Legal, tal vez por la importancia que representan para el registro legal de las víctimas y para la labor de reconstrucción -como de un rompecabezas- de las piezas que conforman las características de hombres y mujeres desaparecidos y que permiten visibilizar los crímenes al tiempo que vislumbrar sus dimensiones. Del cuidado de los procedimientos y de los datos que cuentan los huesos, depende la posibilidad de las familias de encontrar a sus muertos. El papel primordial que juega Medicina Legal en procesos de verdad, justicia y reparación fue puesto en la palestra pública nuevamente de forma reciente, cuando la guerrilla de las FARC y el Gobierno Nacional, en el marco de las negociaciones de paz, acordaron la disposición de todos los elementos necesarios para revelar el paradero de los desaparecidos. Los Escogidos muestra, en últimas, la gran carga de significado que lleva el acto de nombrar para entregarle al muerto la dignidad de la existencia; $y$, la relación entablada con los olvidados como resistencia y como forma de lidiar con la dureza de la realidad. 
De otro lado, Los muertos no se cuentan así, de Mary Daza Orozco (1991), refiere, a partir de la vivencia de la violencia desatada en el Golfo de Urabá, algunos de los acontecimientos de la época, en particular, el exterminio sistemático de sindicalistas y de militantes de la Unión Patriótica -movimiento político representado en la novela como la Nueva Fuerza-, entre ellos, del candidato presidencial de este partido, Bernardo Jaramillo. Su protagonista, Oceana Cayón, es una maestra barranquillera de veinticinco años que se enfrenta a la muerte de su esposo, también profesor y militante de la Nueva Fuerza. Por causa de la búsqueda que emprende -junto con otros dolientes- de los cuerpos de sus familiares secuestrados y desaparecidos, la joven maestra es secuestrada y torturada; el retorno a su tierra le representará la culminación del encierro en sí misma, en el mundo en el que decidió enclaustrarse, incapaz de olvidar y de abandonar la culpa, para protegerse del recuerdo vivo y delirante de su(s) tragedia(s).

Uno de los aspectos que sitúa la obra de Daza es el de los victimarios sin rostro y el desconocimiento de las fuentes de la violencia, referencias constantes en las voces de los distintos personajes de la novela. En las primeras páginas Oceana, además de poner de presente los maestros como víctimas no pensadas pero recurrentes, muestra cómo en el conflicto se da lugar a una confusión en la cual los victimarios se presentan sin rostro y sin entidad, como fuerzas oscuras, extrañas y la violencia como una entidad abstracta. Esta idea se refuerza también en la narración de Oceana sobre la captura de su esposo, además de mostrar algunos de los blancos de las "fuerzas extrañas":

Tú decías que con nosotros no había problema, que con los maestros no se metían, pero lo decías para tranquilizarme [...] Esa noche se lo llevaron con rumbo incierto. Así pasan todas las cosas en la región del Golfo de Urabá. Se llevan las personas y siempre el resultado es la muerte. En raras ocasiones las liberan. Nunca se ha sabido quién es el autor de estas desapariciones y asesinatos. Las víctimas siempre son sindicalistas de las bananeras o miembros de la Nueva Fuerza. Es una persecución también contra campesinos, jueces, periodistas, políticos; así como dijo Adiel Martín: "todos llevamos el sello de la muerte en la frente" (Daza, 2011: 41).

En el brazo del río (Sandoval), Los muertos no se cuentan así (Daza) y Los escogidos (Nieto) -con los textos y las propuestas estéticas que lo acompañan, como es el caso del prólogo de Alfredo Molano de la edición del 2015 y la serie fotográfica Río Abajo de Erika Diettes- comparten la recreación de una imagen que resulta determinante en el conflicto armado colombiano: los “muertos del agua”. Una de las imágenes más estremecedoras es la presentada por Marbel Sandoval, a través de las angustias de Sierva María respecto a la desaparición de Paulina:

El cuerpo de Paulina Lazcarro nunca fue encontrado. Yo pienso que quedó en el buche de los gallinazos o, por qué no, que se enterró en el fondo del río y que alimentó a los coroncoros (...) Antes le decía a mi mamá que los bagres y los conroncoros me sabían a petróleo y ella me regañaba. Ahora, con los años, he optado por callarme, a nadie parece importarle, y a mí se me 
pasó la idea porque lo que pienso es que me estoy comiendo en el sancocho de pescado un poco de Paulina (Relato de Sierva María en Sandoval, 2006: 13).

De otra parte, en su Prólogo de Los Escogidos, Molano reflexiona en torno al río como depositario continuo de muerte, paradoja del agua como condición para la vida, desde los inicios de la violencia en el país, partiendo de la imagen de apertura del libro de Nieto en la que describe su llegada al Pabellón de los Olvidados, -"En el pabellón de caridad las arañas tensan sus hilos de seda y solo gorjea un pajarito...” (Nieto, 2012: 17)-:

Las arañas tejiendo sus atrapamoscas -digo yo- como los pescadores del Magdalena sus redes para pescar cadáveres. El río madre convertido en río de cadáveres -los alberga en su fondo, los bota a las orillas, los desbarata con sus aguas arenosas-; río de muertos, río de muerte. Hace sesenta y tres años que el río es un cementerio de los asesinados en pueblos como Aipe y en ciudades como Neiva. Y en los mil pueblos de las riberas de toda la cuenca. Los matan. Es lo único seguro porque pasan muertos. Pero nadie sabe quiénes son, qué nombre tuvieron, cómo los asesinaron, cómo los destrozaron, cuál fue el último pensamiento antes del gemido final (Molano, 2015: xiii).

La recurrencia de esta mención, llama la atención en torno a un hecho que se configuró como parte de la cotidianidad de las poblaciones rivereñas: el río Magdalena, el más extenso de Colombia, como la gran canal por la que fluyen cuerpos asesinados con sevicia. Nieto enuncia las lógicas de esta operación de terror, el río puede ser un lugar de ocultamiento o de exhibición y funcionar como emisario del horror:

Una vez palpados o vistos, los pepes no se olvidan. Si van entre las aguas y se quedan en la red es porque les han cambiado vísceras por piedras para que viajen a ras del fondo y nadie sepa que van por ahí. Si flotan, aunque sea en pedazos, es porque llevan un mensaje que anticipa el horror que sobrevendrá a quienes no obedezcan las órdenes de los amos de la guerra (Nieto, 2012: 27).

En estos relatos las (os) autoras (es) logran simbolizar las resistencias hacia el olvido y los intentos por dignificar la muerte; asimismo, hacen pensar que los muertos tienen lugar en la memoria pública siempre y cuando se les dote, de una u otra forma, de algún signo de vida, referencia que se torna significativa en la relación vida/muerte que entraña el río y en los claro-oscuros con los que se arma el recuerdo. Este regreso a la vida a través de la palabra es explicado por Molano en los siguientes términos:

Aunque Patricia no lo quiera, ella presta su voz para que los muertos del agua manifiesten sus penas; da sus manos para que "escriban por qué sufren"; ofrece su cuerpo para que "cuenten cómo andan las cosas por allá del otro lado del mundo". Así, al ritmo de las aguas lentas y poderosas del Magdalena. Patricia va sacando personas que cuentan la historia, su historia o la ajena, y hasta la de ella, la de la escritora que tiene tanto de Rulfo -que habla de la vida de los muertos como si estuvieran vivos (Molano, 2015: xvi). 
Marta C. Herrera y Carol Pertuz. Narrativa testimonial y memoria....

Además de las figuras poéticas que ofrece la literatura en relación con el destino de los ríos en el marco del conflicto armado colombiano, la puesta fotográfica de Érika Diettes que acompaña la tercera edición de Los Escogidos recuerda el valor de la rememoración en los procesos de reparación simbólica de las víctimas:

La obra se convierte en una reflexión el papel de los ríos de Colombia como espacio geográfico de evocación de la muerte [...] A través de una poética metáfora visual, Diettes retoma las prendas de los desaparecidos y las fotografía flotando en agua, aludiendo a la presencia de los cadáveres corriendo por un caudal. El proceso de sanación de las victimas inicia al recobrar simbólicamente en estas imágenes la presencia de un cuerpo que no han podido encontrar (Diettes, 2008: s/p).

También trabajos artísticos como el de Magdalenas por el Cauca, de Posada y Ruíz, (2008) que rinde homenaje a los desaparecidos y a sus madres en poblaciones rivereñas del río Cauca, a través de talleres con la comunidad en donde se definen temas e imágenes que a través de actos simbólicos se colocan en balsas que se ponen a navegar en el río, como expresiones de arte efímero inscritas en términos del Land Art que se proponen intervenir el paisaje (Sotto, 2012). "Esta obra fugaz e irrepetible pretende producir en el espectador una experiencia que conmueva sus estructuras de comportamiento y concepción del río, aprovechando la religiosidad de la gente y la energía purificadora y de redención que se manifiesta el 2 de noviembre, Día de las Ánimas del Purgatorio o Día de los Muertos” (Centro Nacional de Memoria Histórica, s.f.).

\section{Las tramas narrativas sobre la violencia política y sus entrecruzamientos en la construcción de la memoria pública}

Uno de los eventos que logra condensar las tensiones que hemos venido mostrando en las narrativas en torno a qué fue lo que pasó, como pasó y quienes fueron sus responsables, tiene que ver con la Toma del Palacio de Justicia, uno de los acontecimientos emblemáticos de la historia reciente, un fenómeno-síntesis, presente, además, en la memoria nacional, pues muchos de los acontecimientos de violencia al transcurrir en circuitos locales no logran trascender para llegar al conocimiento de la opinión pública, para no mencionar el hecho simbólico de ver arder en llamas el recinto de la justicia en Colombia. En el Palacio de Justicia confluyeron años de conflictos sociopolíticos colombianos: el proceso de guerrillas, sus relaciones con el Estado y con las Fuerzas Armadas y las diversas tentativas de negociaciones de paz; las tensiones entre la dirección civil del Estado y las Fuerzas Militares con su histórica oposición a las políticas de paz; las víctimas inocentes de los enfrentamientos entre guerrillas, Ejército y paramilitares; el accionar sistemático de las Fuerzas Armadas en contravía de los derechos humanos; la expresión de un Estado en crisis y todavía en proceso de conformación en buena parte del territorio nacional (Pertuz, 2014); e, incluso -según el informe presentado por la Comisión de la Verdad 
Marta C. Herrera y Carol Pertuz. Narrativa testimonialy memoria....

de los hechos del Palacio de Justicia (2010) y de algunas versiones que circulan a través de distintas narrativas- de los intereses del narcotráfico. En prospectiva, el país no fue el mismo; desde ese momento la guerrilla del M-19 dimensionó los alcances de la represión del Estado, perdió la simpatía de buena parte de la población civil y, no sin tensiones, reforzó la idea de la necesidad de continuar con negociaciones de paz; también marcó una relación de desconfianza de la ciudadanía hacia las instituciones del Estado; se recogieron enseñanzas en lo concerniente a la profesionalidad de las Fuerzas Armadas y al manejo de la política, la Toma fue "la conciencia oculta de la Constitución del 91" (Atehortúa y Vélez, 2005: 11-13, 137-139). Aún en el marco de la Guerra Fría, ésta fue una acción difícil de enmarcar en posturas dualistas y excluyentes de héroes y villanos. Pese a que el Coronel (r) Luis Alfonso Plazas Vega declarara, en medio del combate, ante las cámaras del país que se encontraban defendiendo la democracia, en cientos de colombianos quedó el sinsabor respecto a la legitimidad de las actuaciones de las Fuerzas Armadas, sobre la responsabilidad asumida por el Presidente de la República y la incertidumbre de lo que hubiera ocurrido de haberse optado por la vía del diálogo (Pertuz, 2014).

Y qué hablar del saldo humano: cerca de un centenar de víctimas fatales, entre ellos once magistrados, veintidós servidores públicos, seis empleados, dos visitantes ocasionales, un transeúnte y alrededor de treinta y tres guerrilleros. Según el Grupo de Memoria Histórica, en el informe entregado en 2013, ochenta y nueve personas murieron, entre ellos los once magistrados titulares y veintitrés magistrados auxiliares y abogados suplentes de las Cortes y el Consejo. Otras fuentes reconocen un total de 92 o 98 personas fallecidas. Entre las víctimas se cuentan también los desaparecidos, reconocidos como tales, por primera vez, ocho años después del hecho, en 1993: ocho empleados de la cafetería, tres visitantes ocasionales y una guerrillera, Irma Franco, quien salió con vida del Palacio vestida de civil entre los rehenes, fue reconocida y desapareció bajo la custodia del Ejército Nacional.

Desde las variadas perspectivas de los múltiples actores involucrados de forma directa o indirecta en este acontecimiento se ha declarado y escrito lo que cada uno ha considerado legítimo y necesario para el esclarecimiento de los hechos referentes a lo ocurrido en el Palacio de Justicia. Tal construcción pasa por el reconocimiento social de las voces de las víctimas y demás actores, que en el entretejido de sus relatos configuran, muchas veces de manera conflictiva, las memorias de este acontecimiento tanto a nivel individual como colectivo lo que ha dado pie a múltiples narrativas. Empero, tal reconocimiento no se ha dado en iguales proporciones, tiempos y espacios en todos los casos, cada drama se hace único. El asesinato de los magistrados y servidores públicos, por ejemplo, ha tenido que pasar por la clarificación de las circunstancias de su defunción; se sabe que el manejo dado por la fuerza pública a los cadáveres borró huellas importantes y ha dificultado el develamiento de la verdad de lo ocurrido. Pero estas circunstancias no han puesto en duda su estatuto de víctimas, como se reconoce en la Ley 1056 de 2006 por la cual "se honra la memoria de los magistrados y servidores públicos, víctimas del holocausto del 
Marta C. Herrera y Carol Pertuz. Narrativa testimonialy memoria....

Palacio de Justicia ocurrido durante los días 6 y 7 de noviembre de 1985”. Tal documento resalta también el reconocimiento de los miembros de la fuerza pública fallecidos en los lamentables hechos del 6 y 7 de noviembre de 1985 y se honra su memoria.

Otras víctimas han tenido un tratamiento diferente. Es el caso de los guerrilleros muertos y las personas desaparecidas entre las que se cuentan civiles e insurgentes. Se puede citar el proceso de los desaparecidos empleados de la cafetería cuyo reconocimiento jurídico y social ha costado a sus familias décadas de búsquedas infructuosas y puertas cerradas. Han tenido que lidiar con múltiples versiones acerca de lo ocurrido a sus familiares. Se ha dicho que eran cómplices de los guerrilleros, pues, habrían facilitado el ingreso de provisiones para el tiempo que durara la toma. Se dijo además que, durante la toma, habían sido trasladados por el M-19, al cuarto piso y que habrían muerto por causa de la conflagración que se produjo en ese lugar, motivo por el cual la identificación de los cuerpos habría sido imposible por el grado de calcinación. Desde los días siguientes a la toma, familiares de las personas desaparecidas confluyeron en los lugares de búsqueda y empezaron a crear una red de información. La conciencia acerca de la desaparición de sus seres queridos sobrevino con el trabajo iniciado por el abogado defensor de derechos humanos Eduardo Umaña. Con el tiempo fueron abriendo espacios a partir de los cuales continúan haciendo llamados al Estado y a la sociedad para que se haga justicia y se dignifique la memoria de las víctimas.

La visibilidad que han llegado a recobrar los familiares de los desaparecidos del Palacio de Justicia en tanto víctimas, al punto de convertirse en protagonistas de las narrativas más recientes pasa por un trabajo extenso (tres décadas) por el esclarecimiento de la verdad. Además del deber de memoria, la subjetividad de los familiares de los desaparecidos se reconfigura en torno a un imperativo de lucha en su reconocimiento como grupo y de una causa más grande que la propia. En la novela testimonial Vivir sin los otros. Los desaparecidos del Palacio de Justicia, Fernando González menciona de qué modo la conciencia de la emergencia de una causa se asocia con el encuentro de los familiares de los desaparecidos -en particular de Bety (Pilar Navarrete), la esposa de Ramiro (Héctor Jaime Beltrán) mesero de la cafetería- con el abogado Eduardo Umaña (asesinado en 1998), semanas después de la toma, cuando las respuestas por todas las vías eran cada vez más huidizas:

Con un cigarrillo en la mano, les planteó que aquí no debía hablarse de personas perdidas o cosas por el estilo, sino de colombianos desaparecidos, es decir, ciudadanos que intencionalmente eran víctimas de los Organismos del Estado [...] -El asunto no es de Juan, de José, de María, en fin, de sus familiares que no aparecen; aquí el problema son los desaparecidos en Colombia [...] El problema es que ahora ustedes no solo tiene el derecho sino el deber de luchar por sus familiares y por los más de mil desaparecidos que hoy tenemos [...] Bety recordaría este primer encuentro con el doctor Umaña, no solo como el descubrimiento de su situación personal, sino de su ser social, político y humano (2010: 78-79). 
Este fragmento muestra, además, la manera como los sujetos individuales se reconfiguran en el plano de lo político al convertir un duelo individual en una causa colectiva que deviene en la conformación de organizaciones políticas. De otra parte, las disputas en el terreno de lo simbólico se dan también en el orden de los grupos de personas, de los sujetos sociales que se establecen en lados opuestos de las confrontaciones por instituir la verdad desde sus respectivas versiones y por mostrarse como productores de valores y actuaciones legítimas y positivas para el conjunto de la sociedad. Llama la atención, en este sentido, la mención que hace González a los enfrentamientos entre dos grupos: el que apoyaba al Coronel y el que pedía la condena del militar:

[...] ya se escuchaban las arengas de los dos grupos que se enfrentaban por la verdad de lo ocurrido hacía más de dos décadas. El primero de ellos [...] proclamaba que el Coronel era inocente y que los delitos perpetrados por el M-19 se los querían achacar a él. Una pancarta gigante con la foto del Papa Juan Pablo II dándole la comunión al Coronel, respaldaba los gritos y las consignas a favor de su inocencia. Debajo de esta imagen emblemática se leía: "Coronel, Dios está con usted”. El segundo grupo, lo constituían quienes clamaban por la condena del militar. Como ya era habitual, cada familiar levantaba una letra negra con fondo naranja que formaba la frase Sin Olvido (19).

La lucha librada en el campo jurídico por los familiares de las víctimas tuvo eco en los juzgados casi veintidós años después. En 2007 se dictó orden de captura contra el Coronel (r) Luis Alfonso Plazas Vega al tiempo que en julio de ese mismo año se da inició a las audiencias en torno al caso. Plazas Vega, el mismo que muchos catalogaron como el héroe de la jornada en la retoma fue el primer condenado por la desaparición de los empleados de la cafetería y visitantes ocasionales del Palacio. Con la condena de treinta años proferida a Plazas Vega en el 2010, veinticinco años después de los sucesos, el país confirmó que el 6 y 7 de noviembre de 1985 se cometió, entre otros crímenes de lesa humanidad, el de desaparición forzada. No obstante, la absolución de Plazas Vega se encuentra en discusión.

En Colombia aún observamos fuertes tensiones en el plano jurídico frente al reconocimiento del estatus de víctima a los diferentes actores. Si bien, como mencionamos en la primera parte, en la Ley 1448 de 2011 es claro que los militantes de grupos subversivos no cuentan con estatus de víctimas, el caso de Irma Franco, un guerrillera del M-19 que salió con vida del Palacio y luego fue desaparecida por las Fuerzas Armadas, es reconocido por la Justicia Colombiana y el Estado fue condenado por la Corte Interamericana de Derechos Humanos en 2014. Incluso, este es el único caso de desaparición reconocido por los militares respecto al Palacio, si bien ninguno de los miembros de las Fuerzas Armadas ha asumido culpabilidad.

Esta negación del conflicto y su reducción a un asunto de delincuencia y terrorismo que debía ser combatido y exterminado con las armas implicó un desconocimiento de subjetividades políticas y con ello, se negó toda posibilidad de interlocución. En términos de Jelin, al excluir a la oposición de la 
discusión política se le negó su pertenencia a una comunidad y con ello, su condición de humanidad: "la ausencia de reconocimiento social y político como parte de una comunidad implica [...] un proceso de negación de la condición humana a un grupo o categoría de población, justificando así la aniquilación y el genocidio" (s/f: 93). No obstante, de manera incesante diversas iniciativas introducen narrativas que confrontan las versiones oficiales y pugnan por resignificar la memoria histórica.

\section{Conclusiones}

Si bien el reconocimiento de la figura del sujeto víctima ocupa un lugar importante en determinados procesos, sobre todo los jurídicos, la comprensión de la complejidad del conflicto armado colombiano y de la violencia política que le ha servido de escenario demanda situar otras dimensiones de los sujetos afectados con el propósito de hallar claves que nos permitan comprendernos en tanto sujetos históricos y reconstruir el tejido social fragmentado, cercenado a lo largo de décadas.

A través de las narrativas testimoniales al tiempo que se han visibilizado las víctimas y en muchas ocasiones se les percibe presas de fuerzas que no alcanzan a comprender bajo la impronta de una violencia que parece perpetua y sin modulaciones históricas; también otros relatos señalan su tránsito de víctimas hacia sujetos políticos, o agentes culturales, a través de la acción colectiva; a su vez otros relatos muestran su tránsito de actores armados a sujetos de paz y, en paralelo a ello, las diversas reconfiguraciones subjetivas que dichos trasegares conllevan.

En esta dirección, es importante considerar que las políticas de la memoria no solo hacen referencia a las políticas oficiales y, si bien en ellas se expresan algunas de las tensiones existentes en la sociedad sobre las formas de tramitar el pasado, lo cierto es que los usos políticos de la memoria recorren canales diversos y contribuyen a configurar variados relatos de acuerdo a las apropiaciones que de este pasado hagan los sujetos individuales y colectivos; allí, se ponen en juego prácticas y repertorios políticos y culturales de distinto orden que alimentan la cultura política. Así, esta serie de relatos, dan pie a diversas luchas por la memoria, dentro de las que se encuentran las pugnas por su representación en el campo de las políticas públicas de memoria. 
Marta C. Herrera y Carol Pertuz. Narrativa testimonial y memoria....

\section{Bibliografía}

Abad Colorado, Jesús (2015). Mirar de la vida profunda. Bogotá: Planeta.

Agamben, Giorgio (1998). Homo Sacer. El poder soberano y la nuda vida. Valencia: Pre-textos.

Atehortúa, Adolfo y Vélez, Humberto (2005). ¿Qué pasó en el Palacio de Justicia? Cali: Universidad del Valle.

Behar, Olga (1988). Noches de humo: cómo se planeó y ejecutó la toma del Palacio de Justicia. Bogotá: Planeta.

Carmona-Parra, Jaime (2013). Las niñas de la guerra en Colombia. Manizales: Fondo Editorial UCM.

Castro Caycedo, Germán (2008). El Palacio sin máscara. Bogotá: Planeta.

Centro de Memoria Histórica. "Magdalenas por el Cauca. No más muerte por los ríos de Colombia". Centro Nacional de Memoria Histórica: (s.f.).

Congreso de la República de Colombia. Ley 1408 de 2010. "Por la cual se rinde homenaje a las víctimas del delito de desaparición forzada y se dictan medidas para su localización e identificación”. Diario Oficial núm. 47.807 de agosto 20 de 2010.

Comisión Colombiana de Juristas. "Colombia: en contravía de las recomendaciones internacionales sobre derechos humanos. Balance de la política de seguridad democrática y la situación de derechos humanos y de derecho humanitario”. Comisión Colombiana de Juristas (2004) http:// www.acnur.org/t3/uploads/media/668.pdf?view=1

Cruz, Mery. "Un acercamiento a la palabra femenina en Las horas secretas de Ana María Jaramillo". Poligramas 22 (2005): 42-60.

Daza, Mary (1991). Los muertos no se cuentan así. Bogotá: Plaza y Janés.

Diettes, Erika. Río Abajo. ErikaDiettes (2008): http://www.erikadiettes.com/rioabajo/

Dosse, François (2009). "L'histoire à l'épreuve de la guerre des mémoires”. Tempo e argumento, Florianópolis 1.

Echavarría, Juan Manuel (2013). Réquiem NN. [Documental]. Colombia: Lulu Films y Fundación Puntos de Encuentro.

Franco, Natalia; Nieto, Patricia y Rincón Omar (eds.) (2010). Tácticas y estrategias para contar. Historias de la gente sobre conflicto y reconciliación en Colombia. Bogotá: Centro de Competencia en comunicación para América Latina.

GMH (2009). Memorias en tiempo de guerra. Repertorio de iniciativas. Bogotá: Puntoaparte editores. 
Gómez Gallego, Jorge Aníbal; Herrera Vergara, José Roberto; Pinilla Pinilla, Nilson (2010). Informe final de la Comisión de la Verdad sobre los hechos del Palacio de Justicia. Bogotá: Universidad del Rosario.

González, Fernando (2010). Vivir sin los otros. Los desaparecidos del Palacio de Justicia. Bogotá: Ediciones B.

González, Fernán (2014). Poder y violencia en Colombia. Bogotá: Odecofi-Cinep.

Grabe, Vera (2000). Razones de vida. Bogotá: Planeta.

Grupo de Memoria Histórica (2013) ¡BASTA YA! Colombia: Memorias de guerra y dignidad. Bogotá: Imprenta Nacional.

Iragorri, Juan Carlos (2009). Mi guerra es la paz. Navarro Wolf se confiesa con Juan Carlos Iragorri. Bogotá: Planeta.

Jaramillo, Ana María (1990). Las horas secretas. Bogotá: Planeta.

Jelin, Elizabeth (2007). "Exclusión, memorias y luchas políticas”. Mato, Daniel y Maldonado, Alejandro (comps.). Cultura y transformaciones sociales en tiempos de globalización. Buenos Aires: CLACSO: 91-110.

Jimeno, Ramón (1989). Noche de lobos. Bogotá: Presencia.

Lara, Patricia (1982). Siembra vientos y recogerás tempestades: La historia del M-19, sus protagonistas y sus destinos. Barcelona: Fontmara.

Lara, Patricia (2000). Las mujeres de la guerra. Bogotá: Planeta.

Larrosa, Jorge (1995). Escuela, poder y subjetivación. Madrid: Ediciones de La Piqueta.

Ley de Justicia y Paz 975/2005, de 25 de julio, de Congreso de la República. República de Colombia.

Ley de Víctimas y Restitución de Tierras 1448/2011, de 10 de junio, de Acción Social. República de Colombia.

Ley 1056/2006, de Senado de la República. República de Colombia.

Ley 1408/2010, de agosto 20, de Congreso de la República. República de Colombia.

Lozano, Juan José y Morris, Hollman (2010). Impunity. Suiza/ Francia/ Colombia: Intermezzo Films; Dolce Vita Films.

Molano, Alfredo (2015). “Prólogo”. Nieto, Patricia. Los Escogidos. Medellín: Universidad de Antioquia. Morris, Hollman (2001). Operación Ballena Azul. Las armas del Cantón Norte. Bogotá: Intermedio. 
Morris, Hollman. (2012). Hagamos memoria: La Mujeres de la Unión Patriótica. [Documental]. Colombia: Hollman Morris Producciones y Comunicaciones / Canal Capital.

Moulian, Tomás (1991). Chile actual. Anatomía de un mito. Santiago de Chile: LOM.

Movice. "Historia" MOVICE - Movimiento Nacional de Víctimas (2012).

Nieto, Patricia y Betancur, Jorge Mario (comps.) (2006). Jamás olvidaré tu nombre. Medellín: Alcaldía de Medellín.

Nieto, Patricia (comp.). (2007). El cielo no me abandona. Medellín: Alcaldía de Medellín.

Nieto, Patricia (2012). Los escogidos. Medellín: Sílaba Editores.

Nieto, Patricia (2015). Los escogidos. Medellín: Universidad de Antioquia.

Ochando Aymerich, Carmen (1998). La memoria en el espejo: aproximación a la escritura testimonial. Barcelona: Anthropos.

Ortiz, Lucía. (1997) Voces de la violencia: narrativa testimonial en Colombia.Latin America Studies Association.

Pecaut, Daniel (2001). Guerra contra la Sociedad. Bogotá, Planeta.

Peralta, Andrés y Patiño, Otty (comps.) (2004). Valió la pena. Testimonios de Excombatientes en la vida civil. Bogotá: Intermedio.

Peralta, Andrés (comp.) (2008). La guerra ¿̨para qué? memoria de excombatientes. Bogotá: Alcaldía Mayor de Bogotá.

Peralta, Andrés (2011). La vida no da tregua. Bogotá: Alcaldía Mayor.

Peris, Jaume (2008). Historia del testimonio chileno. De las estrategias de denuncia a las políticas de la memoria. Valencia: Quaderns de Filologia Universitat de València.

Pertuz, Carol. (2014). Vivir sin los otros. Literatura testimonial en la configuración de subjetividades y la constitución de memorias colectivas: aperturas pedagógicas. Trabajo de grado para optar por el título de Licenciada en Psicología. Bogotá: Universidad Pedagógica Nacional.

Pizarro, María José (comp.) (2015). De su puño y letra. Bogotá: Penguin Random House.

Pizarro, María José (2010). Carlos Pizarro: un guerrero de paz. Colombia: Idea Productora.

Pizarro, María José y Hernández, Simón. (2015). Pizarro: la película. Colombia: La Popular.

Posada, Gabriel y Ruíz, Yorlady (2008). Magdalenas por el Cauca. [Exposición-procesión]. Cauca: Ministerio de Cultura. 
Semana. "El lado más íntimo de Carlos Pizarro". Semana.com (2015).

Richard, Nelly (2010). Crítica de la memoria (1990-2010). Santiago de Chile: Ediciones Universidad Diego Portales.

Salazar, Alonso (1993). Mujeres De Fuego. Medellín: Corporación Región para el desarrollo y la democracia.

Sánchez-Blake, Elvira. "Memoria de mujeres en el conflicto colombiano: Reportajes, testimonio y nuevas semantizaciones”. Tercer Milenio. Revista de comunicaciones, periodismo y ciencias sociales 23.

Sandoval, Marbel (2006). En el brazo del río. Medellín: Hombre Nuevo.

Seralde, Milena. "Los archivos de Fabiola Lalinde que lograron reconocimiento de Unesco". El Tiempo (2015).

Semana. "Documentales de la memoria". Semana.com (2015).

Soler, Carlos (s.f.). Esperanza es lo que hay por ahí. [Documental]. Colombia: Carmen Rodríguez y Edgar Murcia.

Sotto, Wilmer. (2012). "Rostro púrpura”. Paisaje de Paisajes. Colombia: Señal Colombia.

Valencia, León (2014). Mis años de Guerra. Bogotá: Aguilar.

Vásquez, María Eugenia (2000). Escrito para no morir. Bitácora de una militancia. Bogotá: Anthropos.

Vélez Rendón, Juan Carlos. "Violencia, memoria y literatura testimonial en Colombia. Entre las memorias literales y las memorias ejemplares”. Estudios Políticos 22 (2003): 31-57.

Verón, Alberto (2011). Víctimas y memorias. Relato testimonial en Colombia. Pereira: Universidad Tecnológica de Pereira.

Vinyes, Ricard (2009). "La memoria del Estado". Vinyes, Ricard. (ed.). El Estado y la memoria. Gobiernos y ciudadanos frente a los traumas de la historia. Barcelona: RBA: 23-66.

Wieviorka, Annette (1998). L’ère du témoin. Paris: Plon. 